\title{
Predation on invasive cane toads (Rhinella marina) by native Australian rodents
}

\author{
Elisa Cabrera-Guzmán • Michael R. Crossland • \\ David Pearson · Jonathan K. Webb • \\ Richard Shine
}

Received: 23 December 2013/ Accepted: 30 March 2014

(c) Springer-Verlag Berlin Heidelberg 2014

\begin{abstract}
The success of an invasive species can be reduced by biotic resistance from the native fauna. For example, an invader that is eaten by native predators is less likely to thrive than one that is invulnerable. The ability of invasive cane toads (Rhinella marina) to spread through Australia has been attributed to the toad's potent defensive chemicals that can be fatal if ingested by native snakes, lizards, marsupials and crocodiles. However, several taxa of native insects and birds are resistant to cane toad toxins. If native rodents are also capable of eating toads (as suggested by anecdotal reports), these large, abundant and voracious predators might reduce toad numbers. Our field observations and laboratory trials confirm that native rodents (Melomys burtoni, Rattus colletti and Rattus tunneyi)
\end{abstract}

Communicated by J. Jacob.

Electronic supplementary material The online version of this article (doi:10.1007/s10340-014-0586-2) contains supplementary material, which is available to authorized users.

E. Cabrera-Guzmán $(\bowtie) \cdot$ M. R. Crossland · R. Shine

School of Biological Sciences A08, University of Sydney,

Sydney, NSW 2006, Australia

e-mail: elicabguz@ebd.csic.es

Present Address:

E. Cabrera-Guzmán

Department of Wetland Ecology, Estación Biológica de Doñana,

CSIC, Seville, Spain

D. Pearson

Department of Parks and Wildlife, PO Box 51, Wanneroo,

WA 6946, Australia

J. K. Webb

School of the Environment, University of Technology Sydney,

Broadway, Sydney, NSW 2007, Australia readily kill and consume cane toads (especially small toads), and are not overtly affected by toad toxins. Captive rodents did not decrease their consumption of toads over successive trials, and ate toads even when alternative food types were available. In combination with anecdotal reports, our data suggest that rodents (both native and invasive) are predators of cane toads in Australia. Despite concerns about the decline of rodents following the invasion of toads, our data suggest that the species we studied are not threatened by toads as toxic prey, and no specific conservation actions are required to ensure their persistence.

Keywords Alien species - Biotic resistance $\cdot$ Bufo marinus $\cdot$ Rhinella marina $\cdot$ Predation $\cdot$ Toxin resistance

\section{Introduction}

Interactions between invasive taxa and native species can affect not only the impact of an invader but also its success or failure in the novel environment. For example, an invader that is readily killed and consumed by native predators is less likely to thrive than one that is invulnerable. Surveys suggest that only a small proportion of translocated taxa thrive in their new environment (Jeschke and Strayer 2006), and one plausible reason for this is biotic resistance (sensu Elton 1958) from native taxa.

Testing this idea in translocated species that fail to establish populations in their new range is difficult; however, even successful invaders that spread widely can be challenged by biotic resistance, which could limit the invader's abundance, distribution and hence its impact (e.g. Dumont et al. 2011).

Although biotic resistance faced by successful invasive species is potentially an important issue, little is known on 
this topic. Cane toads (Rhinella marina) offer an excellent model system with which to explore this question. Toads have thrived since being introduced to Australia in 1935 (Lever 2001), but simple mathematical models suggest that toads in Australia experience around $99 \%$ mortality between the egg and adult stages (Alford et al. 2006). Causes of mortality remain largely unknown. Abiotic and biotic factors (e.g. breeding ponds drying out, predation by aquatic insects and competition with other tadpoles) can cause mortality for eggs and tadpoles (Alford et al. 1995; Cabrera-Guzmán et al. 2012, 2013). Such effects vary through space and time, but in some instances may be highly significant (e.g. $<1 \%$ survival of eggs and hatchlings in the presence of cannibalistic conspecific tadpoles: Alford et al. 1995). In addition, parasitism, cannibalism and predation by ants can reduce survival of metamorph toads (Pizzatto and Shine 2008; Kelehear et al. 2009; Ward-Fear et al. 2010). Predation by vertebrates on this invasive species remains poorly studied (but see, for example, Hamley and Georges 1985; Letnic et al. 2008; Ujvari and Madsen 2009). Conventional wisdom has been that predation by native vertebrate species is unimportant, because the toads have potent chemical defences that are fatal if ingested by native predators (e.g. Covacevich and Archer 1975; Burnett 1997).

Australia lacks native toads, so many lineages of endemic Australian predators have no evolutionary history of exposure to bufonid toxins (Shine 2010). Arrival of toads has caused massive ( $>90 \%)$ population crashes in predators such as blue-tongued skinks, yellow-spotted monitors, northern quolls and freshwater crocodiles (Doody et al. 2006; Letnic et al. 2008; Ujvari and Madsen 2009; PriceRees et al. 2010; Woinarski et al. 2010). In vulnerable vertebrates, toad toxins inhibit the $\mathrm{Na}+\mathrm{K}+$-ATPase enzyme (and thus, disrupt sodium transport across cell membranes), increase myocardial contractility, and cause vasoconstriction and arrhythmia (Flier et al. 1980; Daly et al. 1987; Bagrov et al. 1993). However, there is variation in physiological resistance to bufonid toxins due to interspecific differences in the $\mathrm{Na}+\mathrm{K}+$-ATPase isozyme (Ujvari et al. 2013). For example, many predatory invertebrates are immune to bufadienolides (the cardioactive steroids in the toad's poison) likely due to important differences in structure and physiology between the cardiac systems of invertebrates and those of vertebrates (Schmidt-Rhaesa 2007). Ants, crayfish, dragonfly nymphs, water beetles and water bugs all consume various toad life history stages without ill effect (Crossland and Alford 1998; Ward-Fear et al. 2010; Cabrera-Guzmán et al. 2012). Some vertebrate species exhibit high tolerance to toad toxins, presumably because they have inherited toad-resistance from ancestral Asian taxa exposed to the bufadienolides of Asian bufonids (Llewelyn et al. 2011). Examples include colubrid snakes
(Phillips et al. 2003) and birds (Beckmann and Shine 2009). However, these predators rarely consume toads if alternative prey are available. Llewelyn et al. (2011) found that keelback snakes (Tropidonophis mairii) took native frogs in preference to toads; and Beckmann and Shine (2011) showed that raptors (black kites Milvus migrans and whistling kites Haliastur sphenurus) took the road-killed carcasses of frogs in preference to toads. Despite some anecdotal reports of predation on toads by birds, reviews of this topic have concluded that snakes and birds are unlikely to be significant predators of cane toads in Australia (Beckmann and Shine 2009; Shine 2010; Llewelyn et al. 2011). Potentially, rodents (both native and introduced) could be more important predators of invasive toads. Rodents have a higher tolerance to bufotoxins, perhaps reflecting their biogeographic origins (which include extensive sympatry with bufonids); the tolerance of rodents to bufotoxins also may be related to their physiological resistance to ouabain, a plant cardiac cardenolide (Price and Lingrel 1988; Jaisser et al. 1992). Despite this, surveys have revealed population decline of some rodent species in Australia, and have suggested that poisoning by cane toads may be a potential cause for such declines (Woinarski et al. 2010).

Anecdotal reports suggest that introduced rats (Rattus rattus) and native rats (Hydromys chrysogaster) kill and consume cane toads. Both species have been observed to either consume body parts of toads, or have dead toads present in their nests (Cassels 1966; St. Cloud 1966; Adams 1967; Covacevich and Archer 1975; Fitzgerald 1990). Does this behaviour occur in other rodent taxa, and if so, do rodents only consume toads in the absence of alternative prey? Taste aversion learning is also important, because predators of many species initially attack and consume toads, but soon cease to do so because of conditioned taste aversion (Webb et al. 2008, 2011). If rodents show this pattern also, then rodent predation on cane toads will occur only in naive predators (e.g. in young animals, or in rodent populations as they first encounter invasive toads). To clarify these issues, we reviewed published literature, conducted field observations and ran experimental trials with three species of native rodents that commonly co-occur with cane toads: the dusky rat (Rattus colletti), the pale field rat ( $R$. tunneyi) and the grassland melomys (Melomys burtoni).

\section{Materials and methods}

Field observations

We searched published literature for reports of rodent predation on cane toads, and also assembled observations from our own fieldwork and that of colleagues and others. 
Experimental studies

\section{Study area}

The Adelaide River floodplain lies $60 \mathrm{~km}$ east of the city of Darwin, in the Northern Territory. Maximum monthly temperatures remain above $30^{\circ} \mathrm{C}$ year-round, whereas minimum (overnight) air temperatures are lower mid-year. More than $75 \%$ of the annual rainfall comes in less than 4 months, peaking in the period from January to March. However, rainfall shows stochastic variation over many time-scales (Shine and Brown 2008).

\section{Study species}

The cane toad (R. marina) is native to a wide area of the Americas and was introduced to north-eastern Australia in 1935 as a biological control agent of insect pests of sugar cane (Zug and Zug 1979; Lever 2001). The species has spread through much of tropical and subtropical Australia, and now occurs in Western Australia, a large area of the Northern Territory, most of Queensland and in northern New South Wales (Kearney et al. 2008). In the Australian tropics, metamorphic toads are active by day around the edges of breeding ponds during the dry season, but are dispersed through the landscape during the wet season (Freeland and Kerin 1991; Child et al. 2008a, b). Larger juvenile and adult toads are active at night (Freeland and Kerin 1991) and inhabit a wide variety of habitats, especially anthropogenically disturbed areas (Zug and Zug 1979; Seabrook and Dettmann 1996). Post-larval cane toads span an enormous range of body sizes, from $7 \mathrm{~mm}(<0.1 \mathrm{~g})$ in recently metamorphosed individuals (Child et al. 2008a) to $180 \mathrm{~mm}$ (up to $600 \mathrm{~g}$ ) in adults (Zug and Zug 1979).

The dusky rat (Rattus colletti) is a nocturnal rodent confined to the Northern Territory. Adults range from 60 to $215 \mathrm{~g}$ in body mass and their diet includes seeds, rhizomes, corms, grass, fungus and insects (Watts 1977; Williams 1995; Madsen et al. 2006; Menkhorst and Knight 2011). On monsoonal floodplains, these rats can be extraordinarily abundant, reaching 120-635 rats per hectare and biomass up to 4.7 tons $\mathrm{km}^{-2}$ (Redhead 1979; Madsen et al. 2006).

The pale field rat (Rattus tunneyi) is a nocturnal medium-sized rodent (adults 50-210 g) that occurs over much of Australia (Menkhorst and Knight 2011). This species favours dense vegetation along creeks or rocky slopes, and was once common in northern Australia (Braithwaite and Griffiths 1996). Currently, it is patchily distributed in this area (D. Pearson and J. Webb personal observations). It has declined in recent years, and poisoning by cane toads has been implicated as one possible factor in its decline in the Northern Territory (Woinarski et al. 2010).
The grassland melomys ( $M$. burtoni) is a smaller (adult size 30-120 g: Menkhorst and Knight 2011) nocturnal rodent found in coastal drainage areas of eastern and northern Australia. It feeds on plant stems, grass, seeds, fruits and insects. It inhabits a wide range of habitats and vegetation types (Watts and Aslin 1981; Menkhorst and Woinarski 1992; Kerle 1995; Menkhorst and Knight 2011).

\section{Collection and housing}

Individuals of $M$. burtoni $(n=42$, mean mass \pm SD: $32.2 \pm 6.2 \mathrm{~g})$ and $R$. colletti $(n=43,63.9 \pm 21.0 \mathrm{~g})$ were collected from the Adelaide River floodplain, Northern Territory $\left(12^{\circ} 33^{\prime} 20^{\prime \prime} \mathrm{S}, 131^{\circ} 19^{\prime} 56^{\prime \prime} \mathrm{E}\right.$ and $12^{\circ} 38^{\prime} 59^{\prime \prime} \mathrm{S}, 131^{\circ} 19^{\prime} 47^{\prime \prime} \mathrm{E}$, respectively) where they cooccur with cane toads. Rattus tunneyi $(n=10$, $91.6 \pm 33.7 \mathrm{~g})$ were collected from Mitchell River $\left(14^{\circ} 49^{\prime} 13^{\prime \prime} \mathrm{S}, 125^{\circ} 43^{\prime} 17^{\prime \prime} \mathrm{E}\right)$, Western Australia where toads have yet to invade. At each site, we set approximately 50 aluminium Elliott traps $(33 \times 9 \times 9 \mathrm{~cm})$ in linear transects at $10 \mathrm{~m}$ intervals, baited with rolled oats and vanilla essence or peanut butter. Traps were set at dusk and checked within an hour after sunrise. Captured rodents were weighed, placed in individual calico bags, and taken to the field laboratory (at the Tropical Ecology Research Facility, Middle Point, Northern Territory). Individuals of $R$. tunneyi were air-freighted from Mitchell Plateau to the same field laboratory within four days of capture. All rats were housed in white plastic containers $(60 \times 40 \times 40 \mathrm{~cm}$; with a shelter site, drinking water and bedding: wood shavings) and exposed to a natural lightdark cycle and temperature (13 h light:11 h dark, ambient air temperature $20-30{ }^{\circ} \mathrm{C}$ ). We fed the rats with commercial rodent pellets ad libitum, and these pellets were replenished every 2 days.

Metamorphic and juvenile cane toads were collected by hand in the field within $20 \mathrm{~km}$ of the Tropical Ecology Research Facility, transferred to the field laboratory, and housed in white plastic enclosures that were positioned on a slope (same containers as described above, with water to create a pond at the lower end and prevent toads from dehydrating, plus grass clippings for shelter). The toads were fed insects ad libitum three times a week until they reached a suitable size for experiments $(0.2 \mathrm{~g}$ for metamorphs; $3.5 \mathrm{~g}$ for juveniles). We defined a juvenile toad as an individual larger than $30 \mathrm{~mm}$ snout-urostyle length (SUL) following Cohen and Alford (1993) and Alford et al. (1995). Body sizes (mean \pm SD) of the individuals used in experiments were: metamorph toads: $12.81 \pm 0.81 \mathrm{~mm}$, $0.250 \pm 0.047 \mathrm{~g} ; \quad$ juvenile toads: $42.42 \pm 7.27 \mathrm{~mm}$, $9.74 \pm 5.10 \mathrm{~g}$. 
Table 1 Details of sample sizes and treatments in each laboratory experiment to investigate encounters between cane toads ( $R$. marina) and native Australian rodents (M. burtoni, R. colletti and R. tunneyi)

\begin{tabular}{|c|c|c|c|c|}
\hline $\begin{array}{l}\text { Rodent } \\
\text { species }\end{array}$ & $\begin{array}{l}\text { Experiment } 1 \text {. Rodent } \\
\text { feeding responses to } \\
\text { cane toads }\end{array}$ & $\begin{array}{l}\text { Experiment } 2 . \text { Evidence of taste } \\
\text { aversion (repeated exposure to cane } \\
\text { toads: } 3 \text { nights) }\end{array}$ & $\begin{array}{l}\text { Experiment } 3 \mathrm{~A} \text {. } \\
\text { Consumption of } \\
\text { alternative food }\end{array}$ & $\begin{array}{l}\text { Experiment } 3 \mathrm{~B} \text {. Consumption } \\
\text { of cane toads in presence of } \\
\text { alternative food }\end{array}$ \\
\hline $\begin{array}{l}\text { None (control } \\
\text { treatment) }\end{array}$ & 1 metamorph toad $(n=4)$ & $\begin{array}{l}3 \text { metamorph toads per night } \\
(\text { metamorph toad control) }(n=5)\end{array}$ & $\begin{array}{l}\text { Mixed food (food } \\
\text { control) }(n=9)\end{array}$ & $\begin{array}{l}\text { Mixed food plus } 3 \text { metamorph } \\
\text { toads (control) }(n=8)\end{array}$ \\
\hline $\begin{array}{l}\text { None (control } \\
\text { treatment) }\end{array}$ & 1 juvenile toad $(n=4)$ & $\begin{array}{l}1 \text { juvenile toad per night (juvenile } \\
\text { toad control) }(n=3)\end{array}$ & $\begin{array}{l}3 \text { crickets (control } \\
\text { crickets) }(n=3)\end{array}$ & $\begin{array}{l}3 \text { crickets and } 3 \text { metamorph } \\
\text { toads (control) }(n=5)\end{array}$ \\
\hline $\begin{array}{l}1 \text { Melomys } \\
\text { burtoni }\end{array}$ & $\begin{array}{l}\text { Without a toad present }(M \\
\text { burtoni control) }(n=4)\end{array}$ & $\begin{array}{l}\text { Plus } 3 \text { metamorph toads per night } \\
\quad(n=4)\end{array}$ & $\begin{array}{l}\text { Plus mixed food } \\
\quad(n=11)\end{array}$ & $\begin{array}{l}\text { Plus } 3 \text { metamorph toads } \\
\qquad(n=4)^{\mathrm{a}}\end{array}$ \\
\hline 1 Rattus colletti & $\begin{array}{l}\text { Without a toad present }(R . \\
\text { colletti control })(n=3)\end{array}$ & $\begin{array}{l}\text { Plus } 3 \text { metamorph toads per night } \\
\quad(n=6)\end{array}$ & $\begin{array}{l}\text { Plus mixed food } \\
(n=6)\end{array}$ & $\begin{array}{l}\text { Plus } 3 \text { metamorph toads } \\
\qquad(n=6)^{\mathrm{a}}\end{array}$ \\
\hline $\begin{array}{l}1 \text { Melomys } \\
\text { burtoni }\end{array}$ & $\begin{array}{l}\text { Plus } 1 \text { metamorph toad } \\
\quad(n=5)\end{array}$ & $\begin{array}{l}\text { Plus } 1 \text { juvenile toad per night } \\
\quad(n=2)\end{array}$ & $\begin{array}{l}\text { Plus } 3 \text { crickets } \\
\quad(n=3)\end{array}$ & $\begin{array}{l}\text { Plus mixed food plus } 3 \\
\text { metamorph toads }(n=5)\end{array}$ \\
\hline 1 Rattus colletti & $\begin{array}{l}\text { Plus } 1 \text { metamorph toad } \\
\quad(n=4)\end{array}$ & $\begin{array}{l}\text { Plus } 1 \text { juvenile toad per night } \\
\quad(n=3)\end{array}$ & $\begin{array}{l}\text { Plus } 3 \text { crickets } \\
\quad(n=3)\end{array}$ & $\begin{array}{l}\text { Plus mixed food plus } 3 \\
\quad \text { metamorph toads }(n=5)\end{array}$ \\
\hline $\begin{array}{l}1 \text { Melomys } \\
\text { burtoni }\end{array}$ & Plus 1 juvenile toad $(n=3)$ & - & - & $\begin{array}{l}\text { Plus } 3 \text { crickets and } 3 \\
\text { metamorph toads }(n=5)\end{array}$ \\
\hline 1 Rattus colletti & Plus 1 juvenile toad $(n=6)$ & - & - & $\begin{array}{l}\text { Plus } 3 \text { crickets and } 3 \\
\text { metamorph toads }(n=7)\end{array}$ \\
\hline $\begin{array}{l}1 \text { Rattus } \\
\text { tunneyi }\end{array}$ & Plus 1 juvenile toad $(n=4)$ & $\begin{array}{l}\text { Plus } 1 \text { juvenile toad per night } \\
(n=6)\end{array}$ & - & - \\
\hline
\end{tabular}

For Experiment 3A, Treatment 1 was the control to measure changes in food mass due to desiccation or hydration $n=$ number of experimental replicates

${ }^{a}$ Data for this treatment were obtained from the first night of exposure to M. burtoni and $R$. colletti in Experiment 2

\section{Experimental trials}

All trials were conducted in a field laboratory, in plastic enclosures as described above, but without bedding. Each enclosure contained a PVC tube $(10 \mathrm{~cm}$ length, $6.5 \mathrm{~cm}$ diameter) for shelter (large enough to accommodate a rat), plus a small pond of water. Because these rodents are nocturnal, we added potential food items at 1830 hours and finished the feeding trials at 0700 hours the following morning. We conducted brief observations every hour from 1900 hours until midnight. In the morning, we recorded whether toads were alive or dead, and which body parts had been consumed. Each rodent was used in only a single trial or in a series of three trials (i.e. one night or three consecutive nights at the most, depending on the experiment). Although many individuals were controls (not exposed to toads, crickets or other food items), all rodents were retained for 4 days following experiments to ensure that they did not show any overt effects of consuming toad tissue or any natural mortality. We did not perform all trial types with $R$. tunneyi because insufficient numbers were collected in the field. Overall sample sizes were low for ethical reasons; these trials included potentially fatal predator- prey encounters, so numbers of replicates were restricted to the minimum needed to test whether these rodents are likely to be important predators of toads. In some cases, as a result, those numbers were too low to justify statistical analysis.

Experiment 1: Rodent feeding responses to cane toads

Experiment 1 consisted of nine treatments to test whether the three rodent species consume cane toads, and, if so, whether they survive. In treatments where cane toads and rodents were exposed to each other, we offered a metamorph or a juvenile toad to the rodents (Table 1). We had three to six replicates per treatment, and trials ran for only one night.

Experiment 2: Do rodents show evidence of taste aversion?

To assess whether rodents develop an aversion to feeding on toads, we offered metamorph or juvenile toads to individual rodents for three consecutive nights, using seven treatments (2-6 replicates per treatment, Table 1). Fewer 
juvenile ( 1 per night) than metamorph toads ( 3 per night) were offered to rats due to the larger size of juvenile toads, and the unlikelihood that an individual rat would eat more than one juvenile toad per night. After every trial, we returned the rat to its original enclosure early the following morning. We kept it there (provided with water, food and refugia as described above) until 1830 hours, when it was re-introduced to the (cleaned) experimental enclosure for the next trial with three new metamorph toads or one new juvenile toad.

Experiment 3: Does the availability of alternative food affect rodent predation on cane toads?

We tested if rats will kill and eat cane toads even in the presence of alternative food. First, we tested food consumption and preference by two species of native rodents (R. colletti and M. burtoni) in the absence of toads, by offering each rat $3 \mathrm{~g}$ grass stems, $3 \mathrm{~g}$ sunflower seed kernels, $3 \mathrm{~g}$ cherries and $3 \mathrm{~g}$ raw fish (simultaneously $=$ 'mixed food treatment' below). The grass stems were collected at one of the collection sites of the rats (Anzac Parade, Middle Point, NT). Each food item was set in a small plastic container $(7 \mathrm{~cm}$ diameter, $3 \mathrm{~cm}$ high), with the four containers randomly placed along the centre of the experimental bin. We also offered adult crickets (mean $\pm \mathrm{SD}$ total length: $21.8 \pm 1.76 \mathrm{~mm}$, mass: $0.50 \pm 0.13 \mathrm{~g}$ ) to the rats as another food treatment. We had six treatments with variable numbers of replicates per treatment (Experiment 3A; Table 1). We weighed remaining mixed food items the next morning and counted number of crickets partially or totally consumed. We accounted for mass changes in food items due to loss (grass, cherries, fish) or gain (seeds) of water over the course of trials using the control treatments (Table 1). The percentage mass gained or lost per container was considered to calculate food consumption by rodents.

To assess if the presence of alternative food modifies predation rates on cane toads, or rodent uptake of other food types, we offered rats a choice of toads versus mixed food (described above) or live crickets (Experiment 3B, Table 1). Every trial ran for only one night.

We recorded the first 3-4 h of 15 trials (Experiment 2 with metamorph toads: $M$. burtoni $n=4$ trials, $R$. colletti $n=4$ trials; Experiment 2 with juvenile toads: $M$. burtoni $n=3$ trials, $R$. colletti $n=1$ trial; Experiment $3 \mathrm{~B}$ with metamorph toads: $M$. burtoni $n=2$ trials, $R$. colletti $n=1$ trial) with a video camera and a red light (red globe $25-\mathrm{W}$ ) to document the behaviour of the rats (e.g. whether they attacked toads, time to kill toads, prey manipulation and consumption).
Data analyses

We recorded the condition (alive, dead) of each rodent and toad at the end of each trial, and categorised the consumption of a toad by a rodent as totally consumed, partially consumed or not consumed. For $R$. colletti and $M$. burtoni in Experiment 1 (feeding responses to cane toads), we compared the number of live and dead cane toads in the presence and absence of rats using Fisher Exact tests in $\mathrm{R}$ 3.0.3 software (R Core Team 2013). We did not formally analyse data obtained in Experiment 2 (taste aversion) due to obvious patterns in the results, and low numbers of replicates for some trials. For Experiments $3 \mathrm{~A}$ and $3 \mathrm{~B}$ (consumption of mixed food and consumption of cane toads in the presence of mixed food or crickets), we used Kruskal-Wallis tests in JMP 5.0.1 software (SAS 2002) to assess preferences by rodents in the mixed food treatment. We used the mass change of food items (proportion consumed) as the response variable, and the type of food offered as the explanatory variable. Whether or not the presence of alternative food modified the predation rates on toads by rats and their consumption behaviour (tested in Experiment 3B) was simply described; we did not apply statistical tests to these data (for the reasons explained above).

\section{Results}

\section{Field observations}

Combining published records with field observations, it is clear that two rodent species, the water rat (Hydromys chrysogaster) and the black rat (Rattus rattus) eat cane toads. Both species have been observed to consume toad tissue, or have dead toads present in their nest sites in the Northern Territory, in Queensland and/or New South Wales. Hydromys chrysogaster has been observed directly attacking an adult toad (Electronic Supplementary Material 1). Predation occurs in both urban and rural areas. In some instances where partially consumed toad carcasses have been found in the field, but the predator has not been directly observed, injuries on these carcasses implicate rodent predation. The most likely alternate predators are birds (especially raptors and egrets) that either eat small toads whole (McKilligan 1984) or selectively remove only the tongue of large toads and associated musculature (Beckmann and Shine 2011), resulting in injuries that are inconsistent with those described here. Most other native species do not eat toads (Shine 2010). Cases where other body parts of toads such as internal organs are consumed (a common observation in our study site: G. P. Brown personal communications) are consistent with predation or 
scavenging by rodents (Electronic Supplementary Material 1). Importantly, predators did not consume parotoid glands of any dead adult toads found in the field.

\section{Experimental studies}

\section{General observations}

In the control treatments, all rodents, toads and crickets survived. Rats that were offered cane toads either attacked and killed the toads within a few seconds after the start of trials, or ignored them throughout the trials. Rats often responded to movement by toads, seizing metamorphs with the mouth and seizing juveniles with both the mouth and the paws. The toads were killed by bites to the head or body, and then consumed either partially (including parotoid glands in many instances) or totally. Consumption usually occurred within a few minutes of the attack, but sometimes was postponed for hours. Some rats took toad carcasses back to the shelter site to consume them. Metamorph and juvenile toads that survived exposure to rats were uninjured, and analysis of videotapes showed no evidence of attacks on these individuals.

\section{Experiment 1: Rodent feeding responses to cane toads}

Both metamorph and juvenile toads were killed and consumed by $M$. burtoni and $R$. colletti. Although $R$. tunneyi were not tested with metamorph toads, they did kill and consume juvenile toads (Electronic Supplementary Material 2). Mortality rates of metamorph toads were significantly increased by exposure to $M$. burtoni (Fisher Exact $P=0.048$ ) and $R$. colletti (Fisher Exact $P=0.029$ ). In addition to killing metamorph toads, some $M$. burtoni and $R$. colletti also killed juvenile toads. However, the mortality of juvenile toads in the presence of these predators was not statistically different from mortality in the control treatment (M. burtoni, Fisher Exact $P=0.429 ; R$. colletti, $P=0.476$ ).

In all four cases where a $M$. burtoni killed a metamorph toad, it consumed the entire toad. In the case of $R$. colletti, three of the metamorphs killed were totally consumed and one was partially consumed. The only juvenile toad killed by $M$. burtoni was partially consumed, whereas one of the two juvenile toads killed by $R$. colletti was fully consumed and the other was partially eaten. All four $R$. tunneyi killed the offered juvenile toads; two toads were uneaten, and two were partially consumed. All rats survived the trials, and displayed no overt symptoms of toad poisoning. We did not observe symptoms of poisoning such as panting, contractions or convulsion in the rats, as reported for the marsupial Dasyurus geoffroii (Covacevich and Archer 1975) or unsteady gait, loss of righting ability, incapacitation or tremors, as observed in Planigale maculata and Sminthopsis virginiae after consuming metamorph toads (Webb et al. 2008, 2011).

Experiment 2: Do rodents show evidence of taste aversion?

Toads exposed to rats suffered high levels of mortality during the three consecutive nights of the trials. Mortality of metamorphs exposed to M. burtoni and $R$. colletti was higher than in the control treatment. Both rat species killed similar numbers of metamorphs on each of the three nights ( 2 or 3 of the 3 toads offered to them were killed each night: $M$. burtoni $n=12 / 12$ encounters; $R$. colletti $n=17 /$ 18 encounters; Fig. 1) with only one $R$. colletti as the exception (3, 3, 1 metamorphs killed on the consecutive nights). Similarly, of the metamorphs that were killed, the number of individuals that were fully consumed did not decline over the three nights. All M. burtoni and R. colletti completely consumed as many, or more, metamorph toads on night 3 as on night 1 (Fig. 2). As before, all rats survived the three nights of trials, with no overt symptoms of poisoning.

In the same way, the data for predation on juvenile toads show no evidence of taste aversion learning. One of the two $M$. burtoni exposed to juvenile cane toads over three nights did not attack any toads, whereas the other killed and partially consumed toads on the first two nights but did not attack on the third night. For $R$. colletti, one of the three individuals did not attack any juvenile toads, one killed and totally consumed its toad every night, and the third individual ignored the toad on the first night, but killed and partially consumed the toads that were available during the

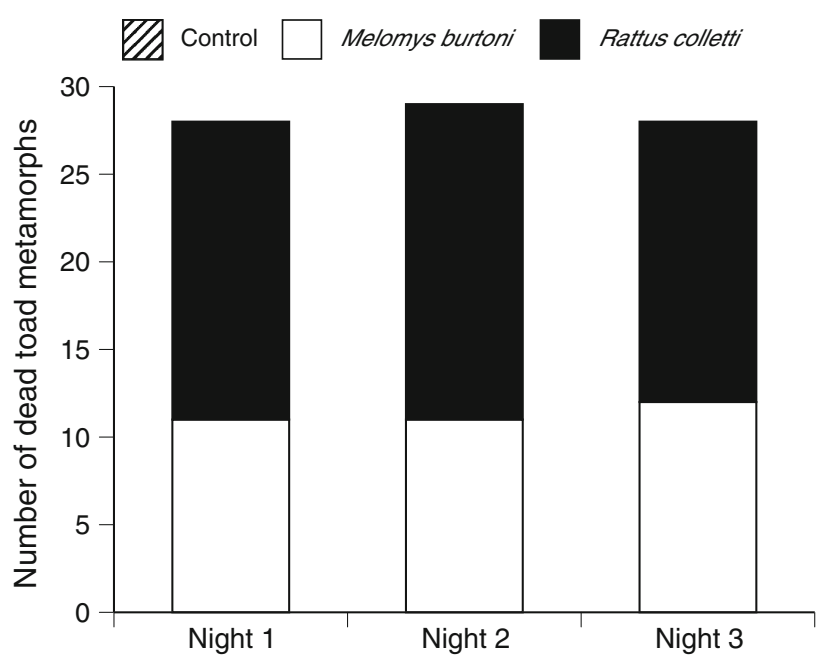

Fig. 1 Number of cane toad metamorphs (R. marina) killed when exposed to rodents (M. burtoni, $n=4$ and $R$. colletti, $n=6$ ) during three subsequent nights 
(a) Melomys burtoni

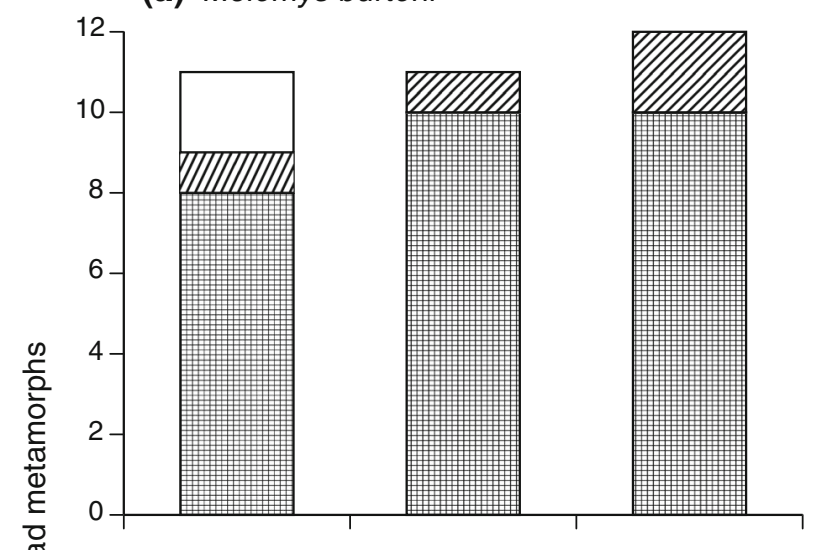

(b) Rattus colletti

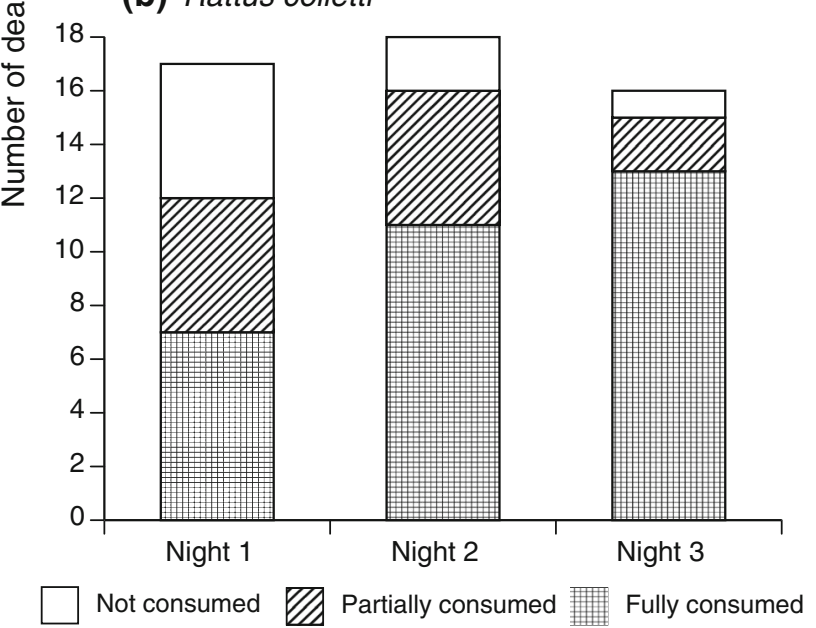

Fig. 2 Number of cane toad metamorphs (R. marina) fully consumed, partially consumed, or not consumed by a $M$. burtoni, $n=4$ and $\mathbf{b}$. colletti, $n=6$ in three subsequent nights

second and third nights. Of the six R. tunneyi, four ignored toads on each night, one ignored toads on nights 1 and 2 but totally ate the toad on night 3 , and one partially ate the toad on night 1 and totally ate the toads on nights 2 and 3 . The mass of the juvenile toads totally consumed by the rats (R. colletti or R. tunneyi) ranged from 6.2 to $13.3 \mathrm{~g}$.

Experiment 3: Does the availability of alternative food affect rodent predation on cane toads?

In the mixed food treatment (Experiment 3A), both $M$. burtoni and $R$. colletti consumed all food types offered. Melomys burtoni showed significant preferences (KruskalWallis: $\left.\chi^{2}=35.21, d f=3, P<0.0001\right)$, with high mean consumption of cherries and seeds $(>50 \%)$ and low mean consumption of grass and fish $(<10 \%)$. $R$. colletti did not show clear preferences $\left(\chi^{2}=1.42, d f=3, P=0.700\right)$. Melomys burtoni and $R$. colletti readily killed and

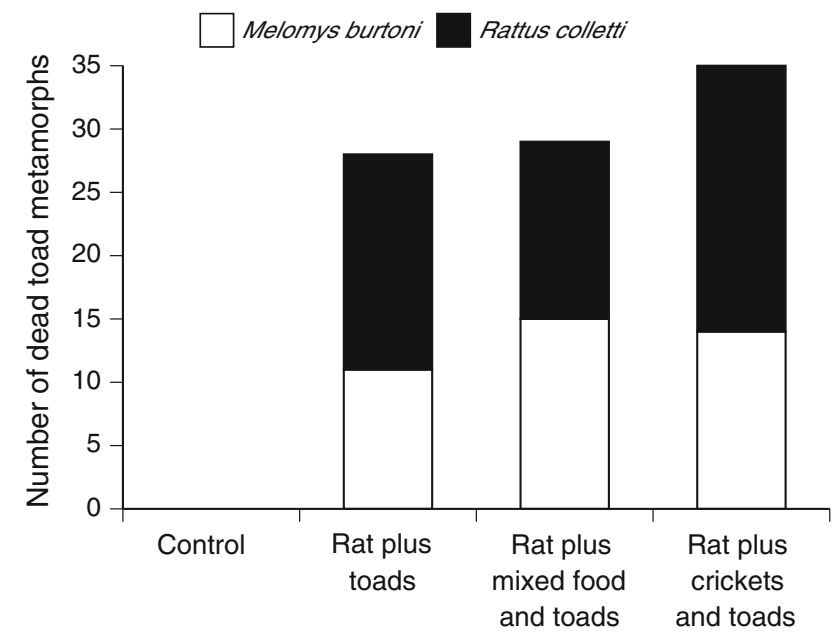

Fig. 3 Number of cane toad metamorphs (R. marina) killed when offered to rodents (M. burtoni, $n=10$ and $R$. colletti, $n=12$ ) in the absence and presence of alternative food (mixed food or crickets)

consumed crickets when they were the only prey available (all crickets were killed by both species: M. burtoni: 7/9 crickets completely consumed, 2/9 partially consumed; $R$. colletti completely consumed all crickets).

Regardless of the presence or absence of alternative palatable food (mixed food or crickets, Experiment 3B), all $M$. burtoni and $R$. colletti killed 2 or 3 of the 3 metamorph toads offered to them in a night, similar to the number of toads killed in absence of other food (Fig. 3). The toads that had been killed were totally or partially consumed, despite the presence of alternative food (Fig. 4a, b). All rats were apparently unaffected by their consumption of toads.

Mixed food was consumed even in the presence of toads, either before or after rodents killed and/or consumed the toads. Food preferences of rodents were unaffected by the presence of toads: preferences by M. burtoni differed significantly (Kruskal-Wallis: $\chi^{2}=15.38, \quad d f=3$, $P=0.001)$ with high mean consumption of cherries and seeds $(>50 \%)$ and low mean consumption of grass and fish $(<15 \%)$. R. colletti did not show significant food preferences (Kruskal-Wallis: $\chi^{2}=5.026, d f=3, P=0.169$ ). The rate of cricket mortality and consumption was not overtly affected by the presence of toad metamorphs $(M$. burtoni: 10/15 crickets killed, 7/10 completely consumed, 2/10 partially consumed; $R$. colletti: all crickets killed, 17/21 completely consumed, $3 / 21$ partially consumed).

\section{Discussion}

Recent studies in Australia have suggested that poisoning by cane toads may threaten some types of mammals 
(a) Melomys burtoni

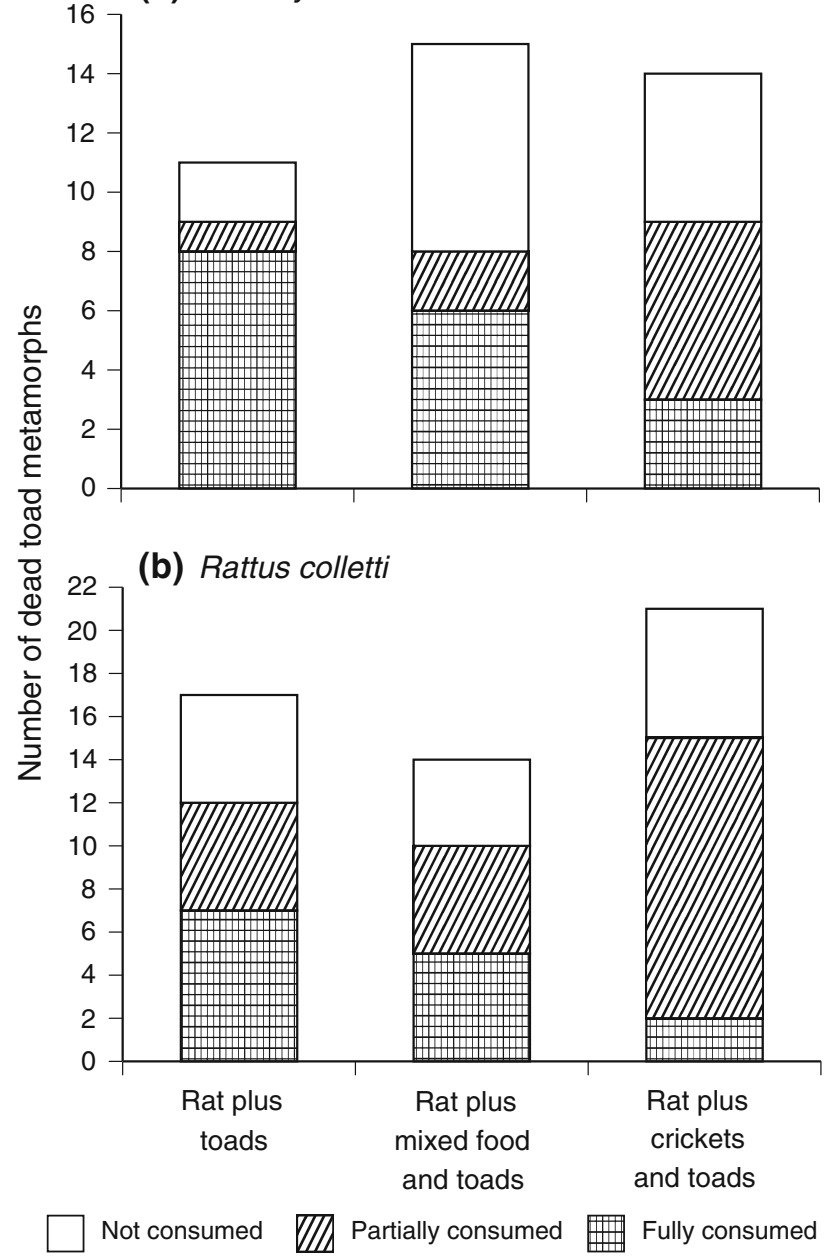

Fig. 4 Number of cane toad metamorphs ( $R$. marina) fully consumed, partially consumed and not consumed in the absence and presence of alternative food (mixed food or crickets) by a M. burtoni, $n=10$ and $\mathbf{b} R$. colletti, $n=12$

including rodents (Woinarski et al. 2010). In contrast, our data indicate that rather than threatening rodent populations, invasive cane toads represent an additional food source for these animals. Our laboratory results demonstrate that three species of native rodents (a) readily kill and eat toads; (b) do not suffer overt ill effects from consuming toad tissue; and (c) continue to eat toads after their initial exposure, rather than excluding toads from the diet due to conditioned taste aversion. Published information, our observations in the field, and our results from experimental feeding trials, all show that Australian rodents can prey upon live cane toads (and likely, also scavenge upon their bodies) with no apparent ill effects on the rat's health or behaviour. Many rodents are opportunistic omnivores (Watts and Aslin 1981; Breed and Ford 2007) and both captive and wild rats have been observed attacking and consuming anurans (Bernard 1974; Watts and Aslin 1981;
Posner and Miley 1982; Thurley and Bell 1994; Olsen 1995; Smales and Cribb 1997).

Extrapolating the results of our experiments to the wild (i.e. to the occurrence of predation on cane toads by rats in nature) is difficult. However, anecdotal observations confirm instances of predation on toads by both native rats $(H$. chrysogaster) and introduced rats ( $R$. rattus; Cassels 1966; St. Cloud 1966; Adams 1967; Fitzgerald 1990). The frequent discovery of partly consumed bodies of toads, and high predation rates on radio-tracked toads in dense vegetation where birds would be unable to attack them (G. P. Brown, personal communications-Electronic Supplementary Material 1) further support the inference that rodents are important predators on invasive toads in tropical Australia.

Although rodents are capable of taste aversion learning (Rozin and Kalat 1971), they are physiologically capable of dealing with many toxins present in tissues of both plants and animals (e.g. alkaloids, cardiac glycosides, glucosinolates, tannins-Ruiz et al. 1977; Glendinning 1990; Xiao et al. 2008; Samuni-Blank et al. 2013). Predators are unlikely to develop taste aversion to a given prey type if they cannot detect it by taste, if they obtain nutritional benefit from it, or if they are not imperilled by the toxins that it contains. This appears to be the case with cane toad tissues. In our experiments, M. burtoni, $R$. colletti and $R$. tunneyi continued to consume metamorphosed or juvenile toads over three consecutive nights. It remains possible that aversion might develop over a longer term, but the effects of bufadienalide poisoning have very rapid onset (within 10-25 min after toad consumption; Webb et al. 2008, 2011). It is more likely that rodents tolerate toad toxins, as our experimental individuals did not show any effects of poisoning over 4 days. In the wild, rats are exposed to a wide array of potential food types, so that consumption of a given food in the laboratory may not translate into consumption of that food in the field (because more palatable items are on offer). However, in the present work $R$. collett $i$ and $M$. burtoni showed no reduction in their rates of toad consumption even when alternative food was provided (Experiment 3B).

Rodents can locate motionless food by scent and taste (Whishaw et al. 1998), but our observations suggest that attacks by all three rodent species occurred in response to movements by prey (toads or crickets). Rattus colletti and M. burtoni consumed small (metamorph) toads at higher rates than larger (juvenile) toads. That difference may reflect ontogenetic changes in toxin contents of the cane toads (metamorphs contain less toxin than juveniles: Hayes et al. 2009). The keelback snake Tropidonophis mairii is resistant to toad toxins, but selectively consumes ontogenetic stages of the toad that contain less toxin (Llewelyn et al. 2012). Rat responses may be affected not only by 
toxin content but also by prey size per se; some of the smaller rats fled from larger juvenile toads rather than attacking them. Although our sample sizes are small, the $R$. colletti and $R$. tunneyi that attacked and killed large (juvenile) toads on all three nights of their trials were the largest individuals that we tested (117.5 and $158 \mathrm{~g}$, respectively). Thus, prey size relative to predator size may influence propensity to attack and or consume (e.g. Paine 1976). As a result, even large adult cane toads may be at risk from large rat species such as Hydromys chrysogaster (up to $1,200 \mathrm{~g}$ ) and Rattus rattus (up to $300 \mathrm{~g}$ ). Interestingly, field observations on large toads attacked by rats and toad carcasses found in rat burrows or on the edge of waterbodies, suggest selective feeding on soft toad body parts that are low in toxin content, but some rats eat most of the toads' skin, organs and muscle (see Electronic Supplementary Material 1). Although predation is difficult to observe in the field, the food-hoarding behaviour of some rodents (Watts and Aslin 1981) might provide an opportunity for more extensive studies on predation of cane toads by other species of rodents in Australia.

At an ecological level, how significant is rodent predation on cane toads? That is, do cane toads increase food availability for rodents, and does predation by rodents substantially reduce cane toad abundance? We can only speculate as to the answers to those questions. Toad arrival will have both direct and indirect effects on food availability for rats. In terms of direct effects (rats eating toads), the biomass of these slow-moving easily-captured prey can be very high (Ward-Fear et al. 2009), especially in the years immediately following toad arrival at a site (Freeland 1986). Indirect effects may well be even greater. Fatal toxic ingestion of toads virtually eliminates populations of previously-common predators such as large varanid lizards and quolls (Ujvari and Madsen 2009; Woinarski et al. 2010), thereby reducing predation on rats, as well as enhancing the abundance of taxa that were the prey of those impacted predators (Doody et al. 2006; Shine 2010; Brown et al. 2013). Other interactions such as competition for food between native rodents and adult toads are unlikely to be important. Insects (mainly grasshoppers) comprise a small proportion of the rodents' diet (Watts 1977; Kerle 1995; Menkhorst and Knight 2011), whereas adult toads prey mostly on insects, occasionally on other arthropods and rarely on vertebrates (Zug and Zug 1979; Freeland et al. 1986). In combination, then, toad invasion could conceivably increase rat numbers and stated concerns about declines of rodents in Australia due to toad invasion (e.g. Woinarski et al. 2010) can be reviewed in light of our findings.

Whether or not predation by rats affects toad population densities is a more difficult question. Despite the high fecundity of cane toads, their populations in Australia may be sensitive to changes in juvenile and adult mortality (Lampo and de Leo 1998); hence, rodent predation could potentially reduce toad densities in areas where rats are abundant. However, large year-to-year fluctuations in abundance of both toads and rats, driven by abiotic factors (especially, rainfall: Redhead 1979; Alford et al. 1995; Madsen and Shine 1999) may obscure (and perhaps, weaken) any influence of predators on toad demography, as well as effects of the availability of toads on rat abundance and demography. Nonetheless, one clear result from recent research is that cane toads in Australia are vulnerable to predation by a wider range of native species than was previously assumed to be the case (Ward-Fear et al. 2010; Beckmann and Shine 2011; Cabrera-Guzmán et al. 2012). The present study adds rodents to that list of toad predators. Biotic resistance to the Australian invasion, thus may be an important constraint on cane toad success; some native predators can potentially reduce the numbers of individuals of this species and may help to explain the often-reported decline in toad abundance postcolonisation (Freeland 1986).

Acknowledgments We thank Lígia Pizzatto, Matt Greenlees, Gregory P. Brown, Joanna Barstow and Rick Lewis for providing field observations of dead toads killed by rodents; Thomas Madsen for advice; Christopher Dickman for confirming rodent identification; Z . Anahí Ávila, Michelle Franklin, Lauren Brown, Kate George, Bill Stewart, and Myfanwy Webb for assistance in the field; Eric Cox, Grant and Lea Hamilton for allowing access to Beatrice Hill Farm, and Melanie Elphick for help in figures preparation. The Northern Territory Land Corporation provided facilities. The work was funded by the Australian Research Council, the Australian Government, the National Council on Science and Technology of Mexico (CONACyT), the Department of Parks and Wildlife (WA), and the University of Sydney. All procedures were approved by the University of Sydney Animal Ethics Committee (Approval Numbers: L04/5-2007/3/4514 and L04/4-2011/2/5472).

\section{References}

Adams NGK (1967) Bufo marinus eaten by Rattus rattus. N Qld Nat 34:5

Alford RA, Cohen MP, Crossland MR, Hearnden MN, James D, Schwarzkopf L (1995) Population biology of Bufo marinus in northern Australia. In: Finlayson M (ed) Wetland research in the wet-dry tropics of Australia. Supervising scientist report 101. Canberra, pp 173-181

Alford RA, Schwarzkopf L, Brown GP, Phillips B, Shine R (2006) Characteristics of Bufo marinus in old and recently established populations. In: Molloy K, Henderson W (eds) Science of cane toad invasion and control. Proceedings of the invasive animals $\mathrm{CRC/CSIRO/Qld} \mathrm{NRM \& W}$ cane toad workshop. Invasive Animals Cooperative Research Centre, Canberra, pp 42-46

Bagrov AY, Roukoyatkina NI, Fedorova OV, Pinaev AG, Ukhanova MV (1993) Digitalis-like and vasoconstrictor effects of endogenous digoxin-like factor(s) from the venom of Bufo marinus toad. Eur J Pharmacol 234:165-172

Beckmann C, Shine R (2009) Impact of invasive cane toads on Australian birds. Conserv Biol 23:1544-1549 
Beckmann C, Shine R (2011) Toad's tongue for breakfast: exploitation of a novel prey type, the invasive cane toad, by scavenging raptors in tropical Australia. Biol Invasions 13:1447-1455

Bernard BK (1974) Frog killing (ranacide) in the male rat: lack of effect of hormonal manipulations. Physiol Behav 12:405-408

Braithwaite RW, Griffiths AD (1996) The paradox of Rattus tunneyi: endangerment of a native pest. Wildl Res 23:1-21

Breed B, Ford F (2007) Native mice and rats. CSIRO Publishing, Australia

Brown GP, Ujvari B, Madsen T, Shine R (2013) Invader impact clarifies the roles of top-down and bottom-up effects on tropical snake populations. Funct Ecol 27:351-361

Burnett S (1997) Colonizing cane toads cause population declines in native predators: reliable anecdotal information and management implications. Pac Conserv Biol 3:65-72

Cabrera-Guzmán E, Crossland MR, Shine R (2012) Predation on the eggs and larvae of invasive cane toads (Rhinella marina) by native aquatic invertebrates in tropical Australia. Biol Conserv 153:1-9

Cabrera-Guzmán E, Crossland MR, Shine R (2013) Competing tadpoles: Australian native frogs affect invasive cane toads (Rhinella marina) in natural waterbodies. Austral Ecol 38: 896-904

Cassels AJ (1966) Disembowelled toads near water. N Qld Nat 34:6

Child T, Phillips BL, Brown GP, Shine R (2008a) The spatial ecology of cane toads (Bufo marinus) in tropical Australia: why do metamorph toads stay near the water? Austral Ecol 33:630-640

Child T, Phillips BL, Shine R (2008b) Abiotic and biotic influences on the dispersal behaviour of metamorph cane toads (Bufo marinus) in tropical Australia. J Exp Zool 309A:215-224

Cohen MP, Alford RA (1993) Growth, survival and activity patterns of recently metamorphosed Bufo marinus. Wildl Res 20:1-13

Covacevich J, Archer M (1975) The distribution of the cane toad Bufo marinus in Australia and its effects on indigenous vertebrates. Mem Qld Mus 17:305-310

Crossland MR, Alford RA (1998) Evaluation of the toxicity of eggs, hatchlings and tadpoles of the introduced cane toad Bufo marinus (Anura: Bufonidae) to native Australian aquatic predators. Aust J Ecol 23:129-137

Daly JW, Myers CW, Whittaker N (1987) Further classification of skin alkaloids from neotropical poison frogs (Dendrobatidae) with a general survey of toxic/noxious substances in the amphibia. Toxicon 25:1023-1095

Doody JS, Green B, Sims R, Rhind D, West P, Steer D (2006) Indirect impacts of invasive cane toads (Bufo marinus) on nest predation in pig-nosed turtles (Carettochelys insculpta). Wildl Res 33:349-354

Dumont CP, Gaymer CF, Thiel M (2011) Predation contributes to invasion resistance of benthic communities against the nonindigenous tunicate Ciona intestinalis. Biol Invasions 13:2023-2034

Elton CS (1958) The ecology of invasions by animals and plants. Methuen, London

Fitzgerald M (1990) Rattus rattus: the introduced black rat, a successful predator on the introduced cane toad Bufo marinus in northern New South Wales. Herpetofauna 20:9-14

Flier J, Edwards MW, Daly JW, Myers CW (1980) Widespread occurrence in frogs and toads of skin compounds interacting with the Ouabain site $\mathrm{Na}+\mathrm{K}+$-ATPase. Science NS 208:503-505

Freeland WJ (1986) Populations of cane toad, Bufo marinus, in relation to time since colonization. Aust Wildl Res 13:321-329

Freeland WJ, Kerin SH (1991) Ontogenic alteration of activity and habitat selection by Bufo marinus. Wildl Res 18:431-443

Freeland WJ, Delvinqueir BLJ, Bonnin B (1986) Food and parasitism of the cane toad, Bufo marinus, in relation to time since colonization. Aust Wildl Res 13:489-499
Glendinning JI (1990) Responses of three mouse species to deterrent chemicals in the monarch butterfly. II Taste tests using intact monarchs. Chemoecology 1:124-130

Hamley T, Georges A (1985) The Australian snapping tortoise Elseya latisternum: a successful predator on the introduced Cane Toad? Aust Zool 21:607-610

Hayes RA, Crossland MR, Hagman M, Capon RJ, Shine R (2009) Ontogenetic variation in the chemical defences of cane toads (Bufo marinus): toxin profiles and effects on predators. J Chem Ecol 35:391-399

Jaisser F, Canessa CM, Horisberger J-D, Rossier BC (1992) Primary sequence and functional expression of a novel ouabain resistant Na, K-ATPase. J Biol Chem 267:16895-16903

Jeschke JM, Strayer DL (2006) Determinants of vertebrate invasion success in Europe and North America. Glob Chang Biol 12:1608-1619

Kearney M, Phillips BL, Tracy CR, Christian KA, Betts G, Porter WP (2008) Modelling species distributions without using species distributions: the cane toad in Australia under current and future climates. Ecography 31:423-434

Kelehear C, Webb JK, Shine R (2009) Rhabdias pseudosphaerocephala infection in Bufo marinus: lung nematodes reduce viability of metamorph cane toads. Parasitology 136:919-927

Kerle JA (1995) Grassland melomys Melomys burtoni. In: Strahan R (ed) The mammals of Australia. Reed New Holland and Australian Museum, Sydney, pp 632-634

Lampo M, de Leo GA (1998) The invasion ecology of Bufo marinus: from South America to Australia. Ecol Appl 8:388-396

Letnic M, Webb JK, Shine R (2008) Invasive cane toads (Bufo marinus) cause mass mortality of freshwater crocodiles (Crocodylus johnstoni) in tropical Australia. Biol Conserv 141:1773-1782

Lever C (2001) The cane toad. The history and ecology of a successful colonist. Westbury Scientific Publishing, Otley

Llewelyn J, Phillips BL, Brown GP, Schwarzkopf L, Alford RA, Shine R (2011) Adaptation or preadaptation: why are keelback snakes (Tropidonophis mairii) less vulnerable to invasive cane toads (Bufo marinus) than are other Australian snakes? Evol Ecol 25:13-24

Llewelyn J, Bell K, Schwarzkopf L, Alford RA, Shine R (2012) Ontogenetic shifts in a prey's chemical defences influence feeding responses of a snake predator. Oecologia 169:965973

Madsen T, Shine R (1999) Rainfall and rats: climatically-driven dynamics of a tropical rodent population. Aust J Ecol 24:80-89

Madsen T, Ujvari B, Shine R, Buttemer W, Olsson M (2006) Size matters: extraordinary rodent abundance on an Australian tropical flood plain. Austral Ecol 31:361-365

McKilligan NG (1984) The food and feeding ecology of the cattle egret, Ardea ibis, when nesting in south-east Queensland. Aust Wildl Res 11:133-144

Menkhorst P, Knight F (2011) A field guide to the mammals of Australia. Oxford University Press, Melbourne

Menkhorst KA, Woinarski JCZ (1992) Distribution of mammals in monsoon rainforests of the Northern Territory. Wildl Res 19:295-316

Olsen PD (1995) Water-rat. In: Strahan R (ed) The mammals of Australia. Reed New Holland and Australian Museum, Sydney, pp 628-629

Paine RT (1976) Size-limited predation: an observational and experimental approach with the Mytilus-Pisaster interaction. Ecology 57:858-873

Pearson D (2009) Government of Western Australia. Department of Environment and Conservation. WA update Cane toad. www. dec.wa.gov.au/publications/doc_download/3583-wa-cane-toadupdate-june-2009.html. Accessed 21 Jan 2013 
Phillips BL, Brown GP, Shine R (2003) Assessing the potential impact of cane toads on Australian snakes. Conserv Biol 17:1738-1747

Pizzatto L, Shine R (2008) The behavioral ecology of cannibalism in cane toads (Bufo marinus). Behav Ecol Sociobiol 63:123-133

Posner I, Miley WM (1982) Discriminative control of interspecific killing in hungry and satiated rats. Anim Learn Behav 10:141-144

Price EM, Lingrel JB (1988) Structure-function relationships in the $\mathrm{Na}, \mathrm{K}-\mathrm{ATPase} \alpha$ subunit: site-directed mutagenesis of glutamine-111 to arginine and asparagine-122 to aspartic-acid generates a ouabain-resistant enzyme. Biochemistry $27: 8400-8408$

Price-Rees SJ, Brown GP, Shine R (2010) Predation on toxic cane toads (Bufo marinus) may imperil bluetongue lizards (Tiliqua scincoides intermedia, Scincidae) in tropical Australia. Wildl Res 37:166-173

R Core Team (2013) R: a language and environment for statistical computing. R Foundation for Statistical Computing. http://www. R-project.org/Vienna

Redhead TD (1979) On the demography of Rattus sordidus colletti in monsoonal Australia. Aust J Ecol 4:115-136

Rozin P, Kalat JW (1971) Specific hungers and poison avoidance as adaptive specializations of learning. Psychol Rev 78:459-486

Ruiz LP Jr, White SF, Hove EL (1977) The alkaloid content of sweet lupin seed used in feeding trials on pigs and rats. Anim Feed Sci Tech 2:59-66

Samuni-Blank M, Izhaki I, Dearing MD, Karasov WH, Gerchman Y, Kohl KD, Lymberakis P, Kurnath P, Arad Z (2013) Physiological and behavioural effects of fruit toxins on seed-predating versus seed-dispersing congeneric rodents. J Exp Biol 216:3667-3673

SAS (2002) JMP 5.0.1. SAS Institute, Cary

Schmidt-Rhaesa A (2007) The evolution of organ systems. Oxford University Press, Oxford

Seabrook WA, Dettmann EB (1996) Roads as activity corridors for cane toads in Australia. J Wildl Manag 60:363-368

Shine R (2010) The ecological impact of invasive cane toads (Bufo marinus) in Australia. Q Rev Biol 85:253-291

Shine R, Brown GP (2008) Adapting to the unpredictable: reproductive biology of vertebrates in the Australian wet-dry tropics. Philos Trans R Soc B 363:363-373

Smales LR, Cribb TH (1997) Helminth parasite communities of the water-rat, Hydromys chrysogaster, from Queensland. Wildlife Res 24:445-457

St. Cloud SF (1966) Observation by J. James at Tinaroo Creek. N Qld Nat 34:6

Thurley T, Bell BD (1994) Habitat Distribution and Predation on a Western Population of Terrestrial Leiopelma (Anura,
Leiopelmatidae) in the Northern King Country, New-Zealand. N Z J Zool 21:431-436

Ujvari B, Madsen T (2009) Increased mortality of naïve varanid lizards after the invasion non-native cane toads (Bufo marinus). Herpetol Conserv Biol 4:248-251

Ujvari B, Mun H, Conigrave AD, Osterkamp J, Bray A, Halling P, Madsen T (2013) Isolation breeds naivety: island living robs Australian varanid lizards of toad-toxin immunity via four-basepair mutation. Evolution 67:289-294

Ward-Fear G, Brown GP, Greenlees MJ, Shine R (2009) Maladaptive traits in invasive species: in Australia, cane toads are more vulnerable to predatory ants than are native frogs. Funct Ecol 23:559-568

Ward-Fear G, Brown GP, Shine R (2010) Factors affecting the vulnerability of cane toads (Bufo marinus) to predation by ants. Biol J Linn Soc 99:738-751

Watts CHS (1977) The foods eaten by some Australian rodents (Muridae). Aust Wildl Res 4:151-157

Watts CHS, Aslin HJ (1981) The rodents of Australia. Angus and Robertson Publishers, Sydney

Webb JK, Brown GP, Child T, Greenlees MJ, Phillips BL, Shine R (2008) A native dasyurid predator (common planigale, Planigale maculata) rapidly learns to avoid a toxic invader. Austral Ecol 33:821-829

Webb JK, Pearson D, Shine R (2011) A small dasyurid predator (Sminthopsis virginiae) rapidly learns to avoid a toxic invader. Wildl Res 38:726-731

Whishaw IQ, Sarna JR, Pellis SM (1998) Evidence for rodentcommon and species-typical limb and digit use in eating, derived from a comparative analysis of ten rodent species. Behav Brain Res 96:79-91

Williams CK (1995) Dusky Rats Rattus colletti. In: Strahan R (ed) The mammals of Australia. Reed New Holland and Australian Museum, Sydney, pp 648-649

Woinarski JCZ, Armstrong M, Brennan K, Fisher A, Griffiths AD, Hill B, Milne DJ, Palmer C, Ward S, Watson M, Winderlich S, Young S (2010) Monitoring indicates rapid and severe decline of native small mammals in Kakadu National Park, northern Australia. Wildl Res 37:116-126

Xiao Z, Chang G, Zhang Z (2008) Testing the high-tannin hypothesis with scatter-hoarding rodents: experimental and field evidence. Anim Behav 75:1235-1241

Zug GR, Zug PB (1979) The Marine Toad, Bufo marinus: a natural history resumé of native populations. Smithson Contrib Zool 284:1-58 